\title{
Vitamin D Binding Protein, Total and Free Vitamin D Levels in Different Physiological and Pathophysiological Conditions
}

\section{OPEN ACCESS}

Edited by:

Giacomina Brunetti,

University of Bari Aldo Moro, Italy

Reviewed by:

lan R. Reid,

The University of Auckland,

New Zealand

Jan Josef Stepan,

Charles University, Czechia

*Correspondence:

Daniel David Bikle

daniel.bikle@ucsf.edu

Specialty section:

This article was submitted to

Bone Research,

a section of the journal

Frontiers in Endocrinology

Received: 25 March 2019

Accepted: 01 May 2019

Published: 28 May 2019

Citation:

Bikle DD and Schwartz J (2019) Vitamin D Binding Protein, Total and

Free Vitamin D Levels in Different

Physiological and Pathophysiological

Conditions. Front. Endocrinol. 10:317.

doi: 10.3389/fendo.2019.00317

\begin{abstract}
Daniel David Bikle ${ }^{1,2 *}$ and Janice Schwartz ${ }^{1}$
${ }^{1}$ Department of Medicine, University of California, San Francisco, San Francisco, CA, United States, ${ }^{2}$ Endocrine Research Unit, San Francisco Veterans Affairs Medical Center, San Francisco, CA, United States
\end{abstract}

This review focuses on the biologic importance of the vitamin D binding protein (DBP) with emphasis on its regulation of total and free vitamin $D$ metabolite levels in various clinical conditions. Nearly all DBP is produced in the liver, where its regulation is influenced by estrogen, glucocorticoids and inflammatory cytokines but not by vitamin $\mathrm{D}$ itself. DBP is the most polymorphic protein known, and different DBP alleles can have substantial impact on its biologic functions. The three most common alleles-Gc1f, Gc1s, Gc2-differ in their affinity with the vitamin D metabolites and have been variably associated with a number of clinical conditions. Although DBP has a number of biologic functions independent of vitamin D, its major biologic function is that of regulating circulating free and total levels of vitamin $D$ metabolites. 25 hydroxyvitamin $\mathrm{D}(25(\mathrm{OH}) \mathrm{D})$ is the best studied form of vitamin $D$ as it provides the best measure of vitamin $D$ status. In a normal non-pregnant individual, approximately $0.03 \%$ of $25(\mathrm{OH}) \mathrm{D}$ is free; $85 \%$ is bound to DBP, $15 \%$ is bound to albumin. The free hormone hypothesis postulates that only free $25(\mathrm{OH}) \mathrm{D}$ can enter cells. This hypothesis is supported by the observation that mice lacking DBP, and therefore with essentially undetectable $25(\mathrm{OH}) \mathrm{D}$ levels, do not show signs of vitamin $D$ deficiency unless put on a vitamin $D$ deficient diet. Similar observations have recently been described in a family with a DBP mutation. This hypothesis also applies to other protein bound lipophilic hormones including glucocorticoids, sex steroids, and thyroid hormone. However, tissues expressing the megalin/cubilin complex, such as the kidney, have the capability of taking up 25(OH)D still bound to DBP, but most tissues rely on the free level. Attempts to calculate the free level using affinity constants generated in a normal individual along with measurement of DBP and total 25(OH)D have not accurately reflected directly measured free levels in a number of clinical conditions. In this review, we examine the impact of different clinical conditions as well as different DBP alleles on the relationship between total and free $25(\mathrm{OH}) \mathrm{D}$, using only data in which the free $25(\mathrm{OH}) \mathrm{D}$ level was directly measured. The major conclusion is that a number of clinical conditions alter this relationship, raising the question whether measuring just total $25(\mathrm{OH}) \mathrm{D}$ might be misleading regarding the assessment of vitamin D status, and such assessment might be improved by measuring free $25(\mathrm{OH}) \mathrm{D}$ instead of or in addition to total $25(\mathrm{OH}) \mathrm{D}$.

Keywords: vitamin D binding protein, vitamin D, free 25(OH)D, free hormone hypothesis, megalin, polymorphisms, liver cirrhosis, pregnancy 


\section{INTRODUCTION}

Vitamin D enters the body either from its production in the skin or absorption from the intestine. In either case, vitamin $\mathrm{D}$ must be transported to tissues such as the liver where it is metabolized to its major circulating form, $25(\mathrm{OH}) \mathrm{D}$, by a variety of enzymes with 25-hydroxylase activity, the major one being CYP2R1. 25(OH)D is then transported to tissues such as the kidney where it gets further metabolized to its biologically active metabolite 1,25 dihydroxyvitamin $\mathrm{D}\left(1,25(\mathrm{OH})_{2} \mathrm{D}\right)$ by the mitochondrial based CYP27B1. CYP24A1, found in most tissues, is the major enzyme catabolizing $1,25(\mathrm{OH}) 2 \mathrm{D}$, thus controlling its impact on a cell specific basis. Vitamin D binding protein (DBP) is the key transport protein which, along with albumin, binds over $99 \%$ of the circulating vitamin D metabolites. For most cells it is the unbound $25(\mathrm{OH}) \mathrm{D}$ that enters cells (free hormone hypothesis), but at least in some cells such as in the kidney, and likely in the parathyroid gland and placenta, DBP participates in the transport of the $25(\mathrm{OH}) \mathrm{D}$ into the cell via a megalin/cubilin complex. Although our focus will be on the transport function of DBP and how that relates to the total and free vitamin D levels in different physiologic and pathophysiologic conditions, DBP has a number of functions independent of its role as a vitamin $\mathrm{D}$ transport protein. These functions will be briefly reviewed as they do contribute to the role DBP plays in health and sickness independent of its role in vitamin D transport. DBP is a highly polymorphic protein with at least 120 isoforms distinguished by electrophoresis. Of these, three major isoforms have received the most interest-Gclf, Gc1s, and Gc2. Their structural differences affect DBP function in ways that have an impact on a number of clinical conditions that will be reviewed.

\section{VITAMIN D BINDING PROTEIN}

\section{Genomic Regulation}

The human DBP gene is located on chromosome 4q12-q13. It is $35 \mathrm{~kb}$ in length and comprised of 13 exons encoding 474 amino acids including a 16 amino acid leader sequence, which is cleaved before release. Numerous tissues express DBP, but the liver is the major source (1). The expression of DBP is increased by estrogen (2) as appreciated with the rise in DBP during pregnancy $(3,4)$ and with oral contraceptive administration (5). However, the exact mechanism for this induction is not clear as a response element for the estrogen receptor in the DBP promoter has not been identified. Androgens, on the other hand, do not appear to affect DBP expression (2). Dexamethasone and certain cytokines such as IL-6 also increase DBP production, whereas TGF $\beta$ is inhibitory (6). As for estrogen, the mechanism underlying such regulation is unclear. However, these cytokines and glucocorticoids are likely to play a role in the increase in DBP production following trauma (after an initial decrease in levels due to actin clearance, see below) (7) and acute liver failure (8), which we will discuss subsequently. Primary hyperparathyroidism, on the other hand, is associated with a reduction in DBP levels, likely contributing to the lower $25(\mathrm{OH}) \mathrm{D}$ levels in these patients as the free $25(\mathrm{OH}) \mathrm{D}$ is not reduced (9). Vitamin D itself or any of its metabolites do not regulate DBP production (10).

\section{Structure and Polymorphisms}

The mature human DBP is approximately $58 \mathrm{kD}$ in size, although differences in glycosylation of the protein for different alleles alter the actual size. DBP is the most polymorphic gene known. Before the appreciation of its role as a carrier of the vitamin D metabolites these polymorphisms in DBP were used by population geneticists to track different populations, referring to the protein as Gc globulin. Over 120 variants have been described based on electrophoretic properties (11) as noted above with 1,242 polymorphisms currently listed in the NCBI database (12). Of these variants, the Gc1f and Gc1s (rs7041 locus) and Gc2 (rs4588 locus) are the most common (Figure 1). Gc1f and Gc1s involve two polymorphisms, one at aa 432 (416 in the mature DBP) and one at 436 (420 in the mature DBP). The If allele encodes the sequence of aa between 432 and 436 as DATPT, the 1s allele encodes the sequence EATPT. This subtle difference in charge makes Gcf run faster (fast) than the Gcs (slow) during electrophoresis. The Gc2 allele encodes DATPK which runs slower still. Glycosylation further distinguishes the $\mathrm{Gc1}$ variants from the Gc2 variant. The threonine (T) in Gc1 binds $\mathrm{N}$-acetylgalactosamine to which galactose and sialic acid bind in tandem. The lysine (K) in comparable position in Gc2 is not glycosylated $(13,14)$. This affects the conversion of DBP to DBP-MAF (macrophage activating factor), which involves a partial deglycosylation removing the galactose and sialic acid by the sequential action of sialidase and $\beta$-galactosidase by $\mathrm{T}$ and B cells (15). The significance of this for the biologic function is described below.

DBP is comprised of 3 structurally similar domains. The first domain is the binding site for the vitamin D metabolites (aa 3549). Fatty acid binding utilizes a single high affinity site for both palmitic acid and arachidonic acid, but only arachidonic acid competes with $25(\mathrm{OH}) \mathrm{D}$ for binding $(16,17)$. The actin binding site is located at aa 373-403, spanning parts of domains 2 and 3 , but part of domain 1 is also involved $(18,19)$. The C5a/C5a des Arg binding site is located at aa 130-149 (20). DBP serves as a cochemotactic factor for $\mathrm{C} 51 / \mathrm{C} 5 \mathrm{a}$ des Arg in its regulation of neutrophil functions (21). Membrane binding sites have been identified in aa $150-172$ and 379-402 (22).

\section{Biologic Function}

\section{Binding to and Transport of Vitamin D Metabolites}

DBP was discovered by Hirschfeld in 1959 (23), and originally called group specific component (Gc-globulin), but it was not until 1975 that its function as a vitamin D transport protein was appreciated (24). In normal individuals, $\sim 85 \%$ of circulating vitamin D metabolites are bound to DBP. Albumin binds $\sim 15 \%$ of these metabolites and does so with much lower affinity. Approximately $0.4 \%$ of total $1,25(\mathrm{OH})_{2} \mathrm{D}_{3}$ and $0.03 \%$ of total $25 \mathrm{OHD}_{3}$ are free in serum from normal non-pregnant individuals. The affinity of DBP for the vitamin $\mathrm{D}_{2}$ metabolites is somewhat less than that for the vitamin $\mathrm{D}_{3}$ metabolites (25). The designation of "bioavailable" vitamin D metabolite is the sum of the free vitamin D metabolite and that bound to albumin, 


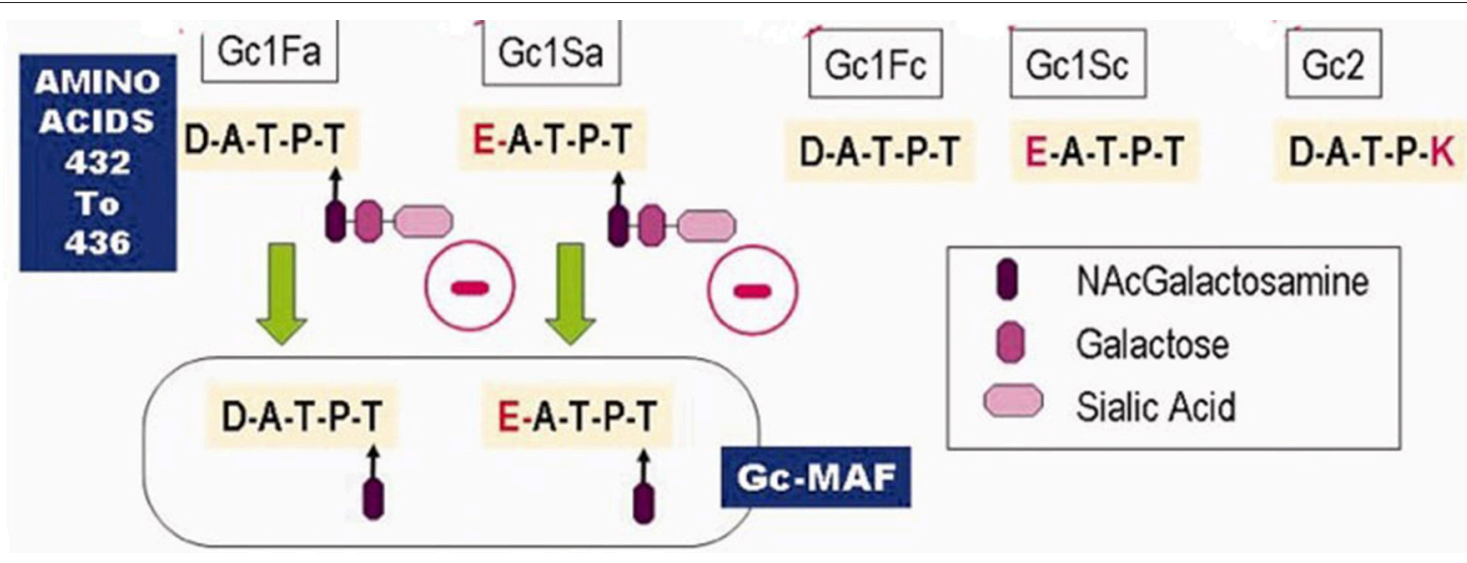

FIGURE 1 | The major DBP alleles. The amino acid differences between the three major DBP alleles are depicted. These differences affect not only their electrophoretic properties but also their glycosylation pattern. In particular Gc2 is not glycosylated, which prevents it from forming the DBP-macrophage activating factor (DBP-MAF). Other biologic differences are discussed in the text.

thus measuring around $15 \%$ in normal individuals [review in (26)]. However, the degree to which the albumin fraction is truly bioavailable is not clear (27). The free hormone hypothesis postulates that only the non-bound fraction (the free fraction) of hormones that otherwise circulate in blood bound to their carrier proteins is able to enter cells and exert their biologic effects. However, at least for some tissues, a transport system has been identified that takes up the $25(\mathrm{OH}) \mathrm{D}$ (and presumably other vitamin D metabolites) attached to DBP. That system involves megalin/cubilin.

The role of megalin for vitamin D metabolism was discovered by Nykjaer et al. (28), who found extensive loss of DBP in the megalin knockout mouse and $25(\mathrm{OH}) \mathrm{D}$ in its urine. These mice have very poor survival rates. More recently, a kidney specific knockout of megalin was developed with a good survival rate, enabling longer term studies that demonstrated reduced circulating levels of the vitamin D metabolites, hypocalcemia, and osteomalacia (29). Cubilin, together with megalin, forms part of the complex facilitating this transport mechanism [review in (30)]. Other tissues express the megalin/cubilin complex including the parathyroid gland and placenta, but its role outside the kidney has received little interest (30). Moreover, activated monocytes may be able to accumulate DBP by a megalin independent process, although this too needs further study $(31,32)$.

The physiologic role of DBP is well-illustrated in the DBP knockout mouse. In these mice the vitamin $\mathrm{D}$ metabolites are presumably all free and/or bioavailable as albumin levels are normal. Unlike the megalin knockout mice, mice lacking DBP do not show evidence of vitamin D deficiency unless placed on a vitamin $\mathrm{D}$ deficient diet despite having very low levels of serum $25(\mathrm{OH}) \mathrm{D}$ and $1,25(\mathrm{OH})_{2} \mathrm{D}$ and increased loss of these metabolites in the urine (33). Tissue levels of $1,25(\mathrm{OH})_{2} \mathrm{D}$ were normal in the DBP knockout mice, and markers of vitamin D function such as expression of intestinal TRPV6, calbindin 9k, PMCA1b, and renal TRPV5 were maintained. Moreover, injection of $1,25(\mathrm{OH})_{2} \mathrm{D}$ into these DBP knockouts showed a more rapid increase in the expression of Cyp24A1, TRPV5, and TRPV6 than in DBP intact controls (34). However, on a vitamin $\mathrm{D}$ deficient diet they quickly developed vitamin $\mathrm{D}$ deficiency. More recently, a family has been described to have a mutation in the DBP gene deleting it from the homozygous patient and decreasing its concentration to $50 \%$ of normal in a heterozygous sibling (35). The homozygous patient had nearly undetectable levels of total $25(\mathrm{OH}) \mathrm{D}$, although the free concentration measured directly was comparable to that of the normal sibling, as was that of the heterozygote sibling. Parathyroid hormone, calcium, and phosphate were all normal. Thus, DBP does not appear necessary for getting the vitamin D metabolites into cells, supporting the free hormone hypothesis, but DBP clearly serves as a critical reservoir for the vitamin $\mathrm{D}$ metabolites, reducing the risk of vitamin $\mathrm{D}$ deficiency when intake or epidermal production is limited.

The DBP alleles have been reported to differ in their affinity to $25(\mathrm{OH}) \mathrm{D}$. Gclf was initially reported as having the highest affinity and Gc2 the lowest among the common alleles (36), but results from other laboratories have not confirmed these differences, and the results from later studies themselves are inconsistent $(37,38)$. In one such study evaluating the half life of $25(\mathrm{OH}) \mathrm{D}$ in serum, subjects homozygous for the Gclf allele were found to have the shortest half life indicating a reduced affinity (39). On the other hand, serum containing the Gclf variant of DBP reduced the ability of $25(\mathrm{OH}) \mathrm{D}$ and $1,25(\mathrm{OH})_{2} \mathrm{D}$ to induce cathelicidin in monocytes more than that of serum with the Gc2 allele, suggesting the opposite order of affinity (31). Schwartz et al. (40) recently reported that DBP haplotype had significant effects on total $25(\mathrm{OH}) \mathrm{D}$, free $25(\mathrm{OH}) \mathrm{D}$, and DBP levels. The lowest total and free levels of $25(\mathrm{OH}) \mathrm{D}$ were seen with the $\mathrm{Gc}$ 2/2 haplotype which also tends to have the lowest DBP levels. Other studies have also found lower total $25(\mathrm{OH}) \mathrm{D}$ levels in subjects with the Gc2 allele (41-45). The reason the Gc2 allele is associated with lower DBP levels is unknown. DBP haplotype also affected percent free $25(\mathrm{OH}) \mathrm{D}$. The lowest free percentage was seen with the $1 \mathrm{~s} / 1 \mathrm{~s}$ haplotype and the highest one with the 
1f/1f haplotype, suggesting that in this survey the Gc1s allele had a higher affinity for 25(OH)D than the Gclf allele, with the Gc2 allele in between. Furthermore, the different Gc alleles affect the response to vitamin D supplementation. Individuals with the Gc2 variant have been shown to respond to vitamin D supplementation with a more robust increase in $25(\mathrm{OH}) \mathrm{D}$ (46). Moreover, within the Gc2 polymorphic region (rs4588), individuals in an Iranian population with an AA genotype within this polymorphic region showed a greater increase in $25(\mathrm{OH}) \mathrm{D}$ levels following vitamin D supplementation than those with the GG genotype did (47). Similar results were found with a different polymorphism at rs2282679 in Caucasian women (48). Rs2282679, an intronic polymorphism in the DBP gene that does not alter DBP structure, was previously shown in GWAS studies to be associated with lower $25(\mathrm{OH}) \mathrm{D}$ and DBP levels in several different populations (49-51). The clinical significance of these allelic differences is unclear. Differences in these alleles were not found to contribute to a difference in fracture rate in a large study including African Americans and Caucasians (52) or other calcemic and cardiometabolic diseases in the Canadian Multicentre Osteoporosis Study (50). However, as reviewed by Malik et al. (13) and Speeckaert et al. (53), a large number of chronic diseases including type 1 and 2 diabetes (54-56), osteoporosis (57-59), chronic obstructive lung disease (60), endometriosis (61), inflammatory bowel disease (62), some cancers (63-66) [although see (66-68)], and tuberculosis (69) have been associated with DBP variants. Other SNPs at rs4588 have been associated with susceptibility to the metabolic syndrome (70). At the Gc1 locus (rs7041) the G allele is associated with increased susceptibility to hepatitis C viral infection (71). Karras et al. (72) has summarized a number of studies showing the impact of DBP and DBP polymorphisms on various outcomes of pregnancy. These studies demonstrate the recent interest in the impact of polymorphisms on DBP function, but it remains to be seen whether these initial results will be generalized across different populations.

\section{Actin Scavenging}

A major function of DBP that has received considerably less interest than that of vitamin $\mathrm{D}$ metabolite binding is its role in actin scavenging. Following trauma (7), sepsis (73-75), liver trauma $(8,76,77)$, acute lung injury $(78)$, preeclampsia (79), surgery $(80,81)$, and burn injuries (82), large amounts of actin are released from the damaged cells forming polymerized filamentous F-actin that, in combination with coagulation factor $\mathrm{Va}$, can lead to disseminated intravascular coagulation and multiorgan failure unless cleared (83). The actin scavenging system consists of gelsolin and DBP. Gelsolin depolymerizes Factin to G (globular) actin. DBP, with its high affinity for G-actin $(\mathrm{Kd}=10 \mathrm{nM})$, prevents the repolymerization and clears it from the blood $(84,85)$. No clear difference among the major DBP variants has been observed regarding binding to G-actin (53). The DBP-actin complexes are rapidly cleared (half life in blood approximately $30 \mathrm{~min}$ ) (81), primarily by the liver, lungs and spleen. These tissues have receptors for the DBP-actin complexes (86). The acute conditions result in a fall in DBP levels, potentially decreasing the bioavailability of the vitamin D metabolites $(8,87$,
$88)$, with a rise in the DBP-actin complexes $(7,73,77,78)$. The ability of the organism to respond to the insult by increasing DBP production is correlated to survival $(7,8,89)$, and has led to the consideration of the use of DBP therapeutically $(90,91)$.

\section{Neutrophil Recruitment and Migration With Complement 5a (C5a) Binding}

Neutrophil activation during inflammation increases their binding sites for DBP (92), and DBP binding to these sites facilitates C5a induced chemotaxis (21) as well as other chemoattractants such as CXCL1 during inflammation (93). The interaction with C5a involves residues 130-149 of DBP, a region which is common to all major DBP alleles (20), and no difference in these alleles has been found with respect to their promotion of C5a mediated chemotaxis (21). Binding of $1,25(\mathrm{OH})_{2} \mathrm{D}$ but not $25(\mathrm{OH}) \mathrm{D}$ blocks the promotion by DBP of C5a activity (94).

\section{Fatty Acid Binding}

DBP binds fatty acids but with lower affinity $\left(\mathrm{Ka}=10^{5}-10^{6} \mathrm{M}^{-1}\right)$ than albumin and via a single binding site $(16,95)$. Most of the fatty acids binding to DBP are mono-unsaturated or saturated, with only $5 \%$ poly-unsaturated. However, only poly-unsaturated fatty acids such as arachidonic acid and linoleic acid compete with vitamin D metabolites for DBP binding $(17,96)$. This suggests that the different fatty acids alter the configuration of DBP affecting the binding of the vitamin D metabolites rather than directly competing with the vitamin $\mathrm{D}$ metabolites for their binding site. The role of DBP in fatty acid transport appears limited.

\section{Formation of the DBP-Macrophage Activating Factor (DBP-MAF) and its Functions}

As described above, DBP-MAF is formed from certain alleles (Gc1s and 1f) of DBP following deglycoslyation during inflammatory processes (97). These deglycosylation steps are required for the role of DBP in macrophage activation (15), but further removal of the $\mathrm{N}$-acetyl-galactosamine (NaGal) reduces this activity (98). DBP-MAF is able to activate osteoclasts (99) independent of its $25(\mathrm{OH}) \mathrm{D}$ binding function, and it has been shown to stimulate bone resorption in the osteopetrosis (OP) and the incisor absent (IA) rat (100). DBP-MAF has also shown efficacy in a number of tumor models (101-103). Removal of $\mathrm{NaGal}$ by $\alpha-\mathrm{NaGalase}$ blocks DBP-MAF formation contributing to the loss of immunosuppression in cancer patients (104). $\alpha$ NaGalase is produced in the liver, and appears to be directly related to tumor burden (105). Preparations of DBP-MAF may have therapeutic potential (14).

\section{FREE HORMONE HYPOTHESIS}

As previously noted, the free hormone hypothesis postulates that only the non-bound fraction (the free fraction) of hormones that otherwise circulates in blood bound to their carrier proteins is able to enter cells and exert their biologic effects (Figure 2). Examples include the vitamin D metabolites, which we are discussing in this review, sex steroids, cortisol, and thyroid hormone. These are lipophilic hormones assumed to cross 


\section{The Free Vitamin 25(OH)D Hypothesis}

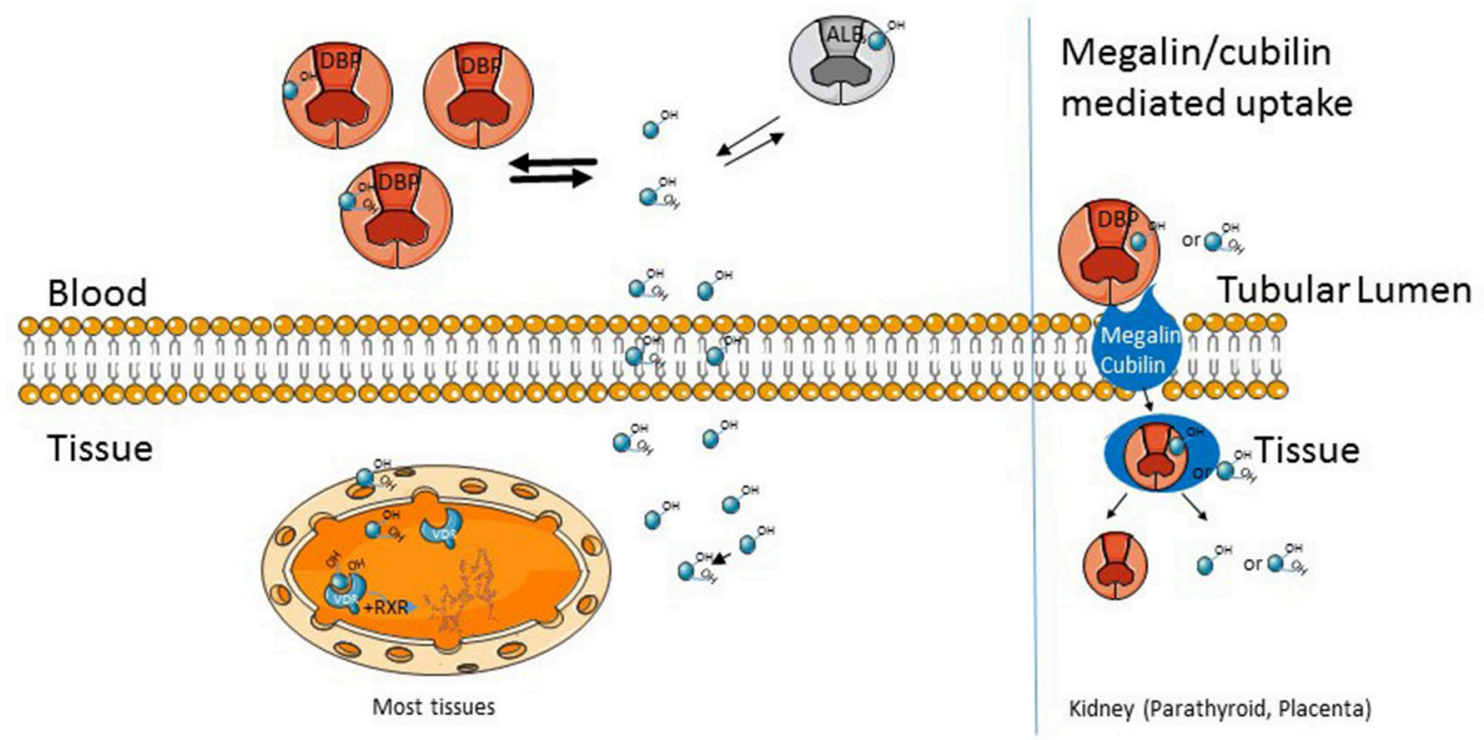

FIGURE 2 | The Free Vitamin D hypothesis. As noted in the text, vitamin $\mathrm{D}(\mathrm{OH})$ metabolites are bound to D Binding Protein (DBP) and to a lesser extent albumin in the circulation. These cross the cell membrane as the free (unbound) metabolite in most tissue. However, In the kidney, parathyroid gland, and placenta, the megalin/cubilin complex can transport bound $\mathrm{D}(\mathrm{OH})$ metabolites into cells.

the plasma membrane by diffusion and not by an active transport mechanism. One of the earliest clinical examples leading to the formulation of the free hormone hypothesis came from observations by Recant and Riggs (106) that patients with protein losing nephropathy developed quite low levels of thyroid hormone (PBI) along with increased urinary losses but without evidence of hypothyroidism. Subsequent studies have established the free hormone hypothesis for the thyroid and steroid hormones $(107,108)$, and measurements of the free concentrations of thyroid hormone, estrogen, and testosterone are standard practice. As will be discussed subsequently, this is likely to become the case for free $25(\mathrm{OH}) \mathrm{D}$. As noted earlier, mice lacking DBP lost substantial amounts of the vitamin $\mathrm{D}$ metabolites in the urine with marked reductions in their circulating levels of $25(\mathrm{OH}) \mathrm{D}$, but they did not develop evidence of rickets until put on a low vitamin D diet. Such results indicate the importance of the free fraction of $25(\mathrm{OH}) \mathrm{D}$ for biologic functions and the role of DBP as a circulating reservoir (33).

To address the clinical relevance of the free hormone hypothesis for vitamin $\mathrm{D}$ metabolites, a method to measure the free concentration needed to be developed. This was originally performed by centrifugal ultrafiltration to directly determine the free levels of $25(\mathrm{OH}) \mathrm{D}$ and $1,25(\mathrm{OH})_{2} \mathrm{D}(109$, 110) in various clinical situations. However, this method is labor intensive and has recently been replaced at least for free $25(\mathrm{OH}) \mathrm{D}$ by a two-step ELISA that directly measures free 25(OH)D (Future Diagnostics Solutions B.V., Wijchen, Netherlands) using monoclonal antibodies from DIAsource Immunoassays (Louvain-la-Neuve, Belgium). The antibody in the current assay does not recognize $25(\mathrm{OH}) \mathrm{D}_{2}$ as well as $25(\mathrm{OH}) \mathrm{D}_{3}\left(77 \%\right.$ of the $25(\mathrm{OH}) \mathrm{D}_{3}$ value), so underestimates the free $25(\mathrm{OH}) \mathrm{D}_{2}$. However, under most situations where the predominant vitamin $\mathrm{D}$ metabolite is $25(\mathrm{OH}) \mathrm{D}_{3}$, the data compare quite well to those obtained from similar populations using the centrifugal ultrafiltration assay $(111,112)$. The initial studies with the centrifugal ultrafiltration method established affinity constants for DBP and albumin binding to $25(\mathrm{OH}) \mathrm{D}$ and $1,25(\mathrm{OH})_{2} \mathrm{D}$ in a healthy young adult (DD Bikle) and may not be generalizable to a broad range of individuals from different ethnic backgrounds or in different clinical conditions. However, prior to the development of a high throughput ELISA assay to measure the free concentration directly, these affinity constants proved useful in calculating the free concentrations $(113,114)$ from measurements of DBP, albumin and the total vitamin D metabolite of interest according to the formula:

free vitamin $D$ metabolite $=\frac{\text { total vitamin } D \text { metabolite }}{1+\left(K a_{\text {alb }} * \text { albumin }\right)+\left(K a_{D B P} * D B P\right)}$

As noted previously, the affinity of $25(\mathrm{OH}) \mathrm{D}$ for albumin is much less that than for DBP, leading some to consider albuminbound 25(OHD) to be essentially "free" or "available" and define "bioavailable $25(\mathrm{OH}) \mathrm{D}$ " as free $25(\mathrm{OH}) \mathrm{D}$ plus albumin-bound $25(\mathrm{OH}) \mathrm{D}$. Given that the albumin bound $25(\mathrm{OH}) \mathrm{D}(15 \%)$ is considerably higher than the free level $(0.03 \%)$, this would imply that approximately 500 times as much $25(\mathrm{OH}) \mathrm{D}$ is available to cells than if only the free fractions were available. There is little evidence to support albumin bound $25(\mathrm{OH}) \mathrm{D}$ as being readily available to cells. 
In sera from normal healthy younger individuals, the calculated values of free $25(\mathrm{OH}) \mathrm{D}$ and $1,25(\mathrm{OH})_{2} \mathrm{D}$ using DBP measured with polyclonal antibodies correlate reasonably well with the directly measured free levels using centrifugal ultrafiltration for both metabolites or the ELISA assay for $25(\mathrm{OH}) \mathrm{D}$. However, when applied to clinical populations with altered DBP levels either during physiologic (e.g., pregnancy) or pathologic (eg. liver disease) conditions, the calculated values no longer are consistent with those measured directly by either centrifugal ultrafiltration or the newly developed ELISA (115). Part of this is due to the disparity between assays for both the vitamin D metabolite (e.g., 25(OH)D) and DBP, each of which have generally relied on immunoassays. However, mass spectroscopy is becoming the gold standard for measurement of the vitamin D metabolites $(116,117)$ and is being developed for the measurement of DBP and its various isoforms as well $(42,118)$. The adoption of mass spectroscopy should reduce the variation in these measurements from different laboratories. But a major problem in attempting to calculate the free fraction of vitamin $\mathrm{D}$ metabolites is the assumption that all DBP alleles have the same affinity for the vitamin $\mathrm{D}$ metabolites, and that this is invariant under varying clinical conditions. As noted previously, the rank order of affinity of the different alleles for the vitamin D metabolites remains controversial, but differences have been found. Regardless, these potential differences in measured affinity do not begin to explain the large differences between the calculated and directly measured free metabolite levels in various disease states (40). Although there are statistically significant correlations between calculated and directly measured free $25(\mathrm{OH}) \mathrm{D}$, the relationship accounts for only $13 \%$ of the variation. Calculated free $25(\mathrm{OH}) \mathrm{D}$ concentrations are consistently higher than directly measured concentrations in a variety of studies, such as those performed during the third trimester of pregnancy and in patients with liver disease or cystic fibrosis $(115,119-$ 122). These studies suggest changes in the affinity of $25(\mathrm{OH}) \mathrm{D}$ to DBP independent of allelic variations in at least some of these clinical conditions.

\section{CLINICAL STUDIES}

\section{Healthy Populations}

Determinations of free $25(\mathrm{OH}) \mathrm{D}$ concentrations in healthy populations show highly significant correlations with total $25(\mathrm{OH}) \mathrm{D}$ concentrations whether measured directly or indirectly. Assays to directly measure free 25(OH)D are not currently available for use in clinical care but have been used in research investigations. As noted above, calculated $25(\mathrm{OH}) \mathrm{D}$ values are usually higher than when measured directly, which is based on multiple unsubstantiated assumptions such that results obtained with the two methods can differ markedly in different clinical conditions. For these reasons only results from studies with directly measured free $25(\mathrm{OH}) \mathrm{D}$ will be discussed. When measured with the direct immunoassay, free $25(\mathrm{OH}) \mathrm{D}$ levels have been reported to be between 0.02 and $0.09 \%$ of total $25(\mathrm{OH}) \mathrm{D}$ concentrations and generally range from 0.5 to $8.1 \mathrm{pg} / \mathrm{mL}$ in $95 \%$ of healthy adults (Figure 3). However, clinical conditions that alter either DBP, the affinity of DBP for

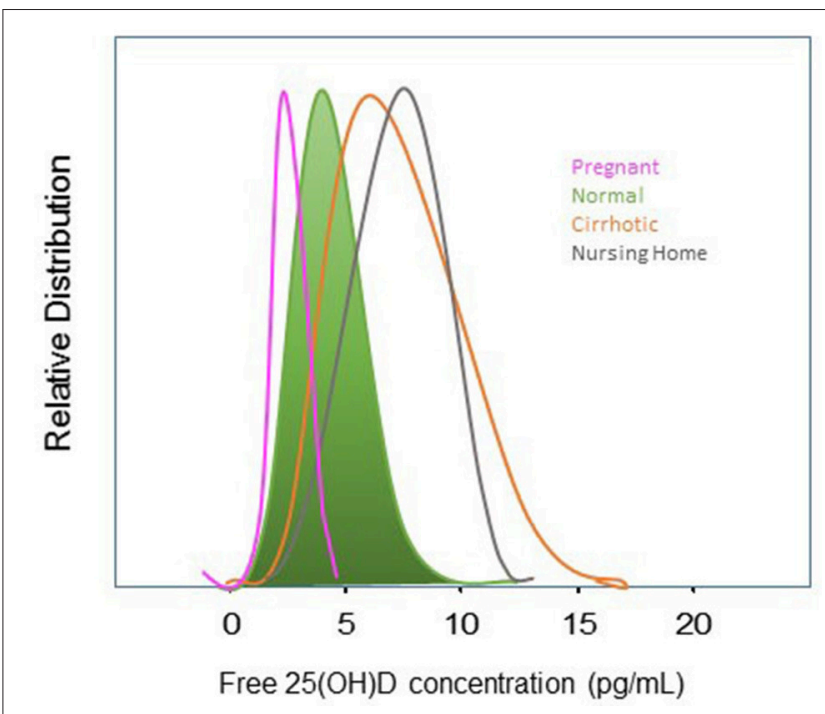

FIGURE 3 | Distribution of free 25(OH)D in Adults and Selected Patient Groups. Distribution of directly-measured free 25(OH)D in normal adults (in green), pregnant women (pink), cirrhotics (orange), and nursing home residents (gray). Distributions are shifted leftward toward lower free 25(OH)D concentrations in pregnant women in the 2nd and 3rd trimesters concordant with increased DBP while decreased synthetic function and DBP in cirrhotics shifts free $25(\mathrm{OH})$ concentrations to the right toward higher levels. The mechanism for higher free $25(\mathrm{OH})$ concentrations in Nursing home residents is likely related to D supplementation, somewhat lower, albumin, and the pro-inflammatory state of frailty. Figure generated form data in Schwartz et al. (40).

25(OH)D metabolites or albumin, or disposition of vitamin $\mathrm{D}$, may alter free $25(\mathrm{OH}) \mathrm{D}$ concentrations or relationships between free and total $25(\mathrm{OH}) \mathrm{D}$ concentrations. In this regard, a number of medications, hormones, and smoking have been shown to affect DBP levels (123). Thus, as shown in Figure 3, the free concentration of $25(\mathrm{OH}) \mathrm{D}$ varies among different clinical conditions. DBP haplotypes have also been hypothesized to alter the affinity between total $25(\mathrm{OH}) \mathrm{D}$ and free $25(\mathrm{OH}) \mathrm{D}$, although, as shown in Figure 4, the variation in percent free $25(\mathrm{OH}) \mathrm{D}$ levels is less affected by DBP haplotype than clinical condition.

\section{Free 25(OH) D in Conditions That Alter DBP Pregnancy}

As pregnancy progresses there are time dependent changes in DBP with almost two-fold increases between the second and third trimesters. Despite these marked DBP changes, mean free $25(\mathrm{OH}) \mathrm{D}$ may be the same as or only slightly lower than in non-pregnant women but with less variability than in other groups $(40,124)$. The slope of the free $25(\mathrm{OH}) \mathrm{D}$ vs. total $25(\mathrm{OH}) \mathrm{D}$ relationship, however, is significantly less steep than in healthy individuals. The same conclusion was drawn from earlier studies with measurements of free $1,25(\mathrm{OH})_{2} \mathrm{D}$ (109). These results suggest that the affinity of DBP for vitamin $\mathrm{D}$ metabolites is decreased during pregnancy, perhaps compensating for increased DBP 


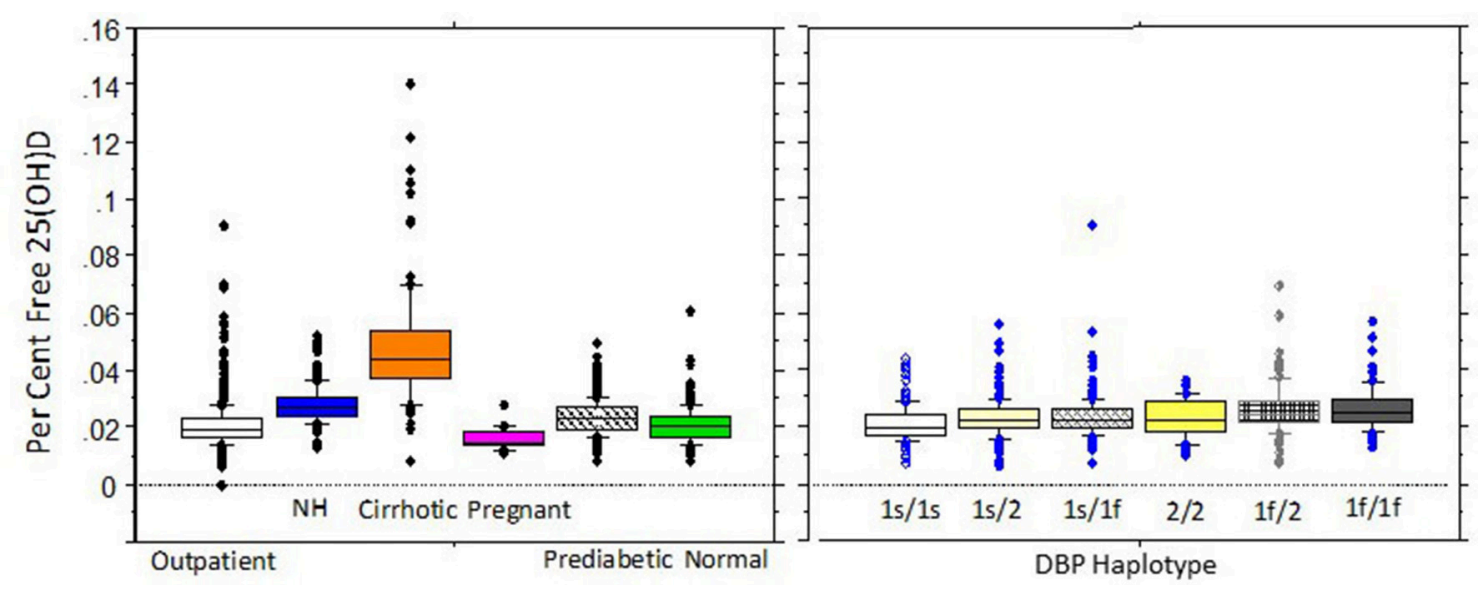

FIGURE 4 | Percent free 25(OH)D in adults by clinical condition or DBP Haplotype. Percent free 25(OH)D concentrations for selected clinical groups on the left panel (community outpatients, $\mathrm{NH}=$ nursing home patients, cirrhotics, pregnant women, prediabetics, and normal individuals) and by DBP haplotype on the right . Boxplots show 10th, 25th, median, 75th, and 90th percentile values. Individual points represent values above the 90th and below the 10th percentiles. Both clinical subgroup and DBP genotype significantly effect percentage free 25(OH)D. Between group comparisons for clinical conditions were significant for all but healthy persons compared with pregnant women or outpatients, or for pregnant women compared with outpatients. For DBP haplotypes, smaller but significant differences were detected between the $1 \mathrm{~s} / 1 \mathrm{~s}$ haplotype and the $1 \mathrm{~s} / 1 \mathrm{f}, 1 \mathrm{f} / 2,1 \mathrm{f} / 1 \mathrm{f}$, and $1 \mathrm{~s} / 2$ haplotypes and between the $1 \mathrm{~s} / 2$ and $1 \mathrm{f} / 2$ and $1 \mathrm{f} / 1 \mathrm{f}$ haplotypes and between the $1 \mathrm{~s} / 1 \mathrm{f}$ and 1f/1f haplotypes. Data are reproduced with permission from Schwartz et al. (40).

concentrations and the needs of both the mother and fetus for calcium.

\section{Liver Disease}

Liver diseases that are associated with impaired protein synthetic function such as cirrhosis and acute liver failure result in reductions in DBP and albumin. In addition, the relationship between free $25(\mathrm{OH}) \mathrm{D}$ and total $25(\mathrm{OH}) \mathrm{D}$ is significantly steeper in patients with cirrhosis than in healthy people indicating altered affinity of DBP for $25(\mathrm{OH}) \mathrm{D}$ (40) (Figure 4). The net result is that directly measured free $25(\mathrm{OH}) \mathrm{D}$ is higher and shows greater variability in patients with cirrhosis compared to healthy individuals and stable outpatients with other chronic conditions $(40,110,115)$ despite lower total $25(\mathrm{OH})$ D concentrations. Results regarding the effects of cirrhosis or acute liver failure on the relationship of total to free $25(\mathrm{OH}) \mathrm{D}$ are consistent, creating a strong argument for assessment of free $25(\mathrm{OH}) \mathrm{D}$ to assess vitamin D status in the presence of liver pathology as total 25(OH)D measurements may be misleading.

\section{Renal Disease}

Nephrotic syndrome, acute renal failure, acute tubular necrosis, or chronic kidney disease associated with renal tubular necrosis may have decreased transport capacity for DBP from the glomerular filtrate into the renal tubules. Heavy proteinuria can lead to loss of DBP as well as $25(\mathrm{OH}) \mathrm{D}$ in the urine as the maximal transport capacity of the megalin/cubulin system is saturated. Reports in the literature have not included direct measurement of free $25(\mathrm{OH}) \mathrm{D}$ in these conditions, but a small study of nephrotics showed lower total and free $1,25(\mathrm{OH})_{2} \mathrm{D}$ compared to people with normal renal function (125).

\section{Clinical Conditions Not Associated With Altered DBP Levels Obesity}

High BMIs are associated with reductions in total and free $25(\mathrm{OH}) \mathrm{D}$ but not DBP or elimination of half-life measurements of $25(\mathrm{OH}) \mathrm{D}$ (126). The underlying mechanism for these changes is unknown but may be related to the pro-inflammatory state and circulating cytokines present in obesity, although increased volume of distribution (into fat) has also been invoked.

\section{DBP Haplotypes}

Investigations using direct measurements of free $25(\mathrm{OH}) \mathrm{D}$ have detected statistically significant but not marked differences in free $25(\mathrm{OH}) \mathrm{D}$ concentrations between healthy individuals with the six common DBP haplotypes (Figure 4). This is in contrast to the marked differences between haplotypes reported with calculated free $25(\mathrm{OH}) \mathrm{D}$ levels $(122,127)$. As noted previously with directly measured free $25(\mathrm{OH}) \mathrm{D}$, the lowest free $25(\mathrm{OH}) \mathrm{D}$ is seen with the Gc 2/2 haplotype and the highest levels with the 1s alleles. Per cent free was highest with the 1f/1f haplotype in our studies (40) (see Figure 4).

\section{Nursing Home Subjects}

In a vitamin $\mathrm{D}$ dose titration study (128) of nursing home residents, who are older, have more chronic co-morbidities, and receive more medications than younger people or communitydwelling elderly, free $25(\mathrm{OH}) \mathrm{D}$ levels rose along with increases in total $25(\mathrm{OH}) \mathrm{D}$. The per cent free was higher than in younger adults. Relationships between free and total 25(OH)D were also steeper than those of normal subjects or younger outpatients suggesting altered affinity of $25(\mathrm{OH}) \mathrm{D}$ to $\mathrm{DBP}$ in this group. Slightly lower albumin concentrations may have also had a small contribution. Inflammation and/or elevated cytokines that 
accompany very old age or multiple morbidities may have also contributed to altered affinity of $25(\mathrm{OH}) \mathrm{D}$ to DBP in this group (129).

\section{Associations With Markers of Vitamin D Biologic Function}

$\mathrm{PTH}$ is generally found to be negatively correlated with free $25(\mathrm{OH}) \mathrm{D}$ as well as total $25(\mathrm{OH}) \mathrm{D}$. Reports variably conclude that one or the other shows a slightly more significant relationship, but neither explains more than a small amount of the variability in the relationship. Moreover, if the megalin/cubilin complex is operative in the parathyroid gland as it is in the kidney, PTH levels may not be able to distinguish between free and total $25(\mathrm{OH}) \mathrm{D}$ with respect to biologic action. However, further insight into the impact of free vs. total $25(\mathrm{OH}) \mathrm{D}$ on PTH levels may be gained from several recent studies showing that with high dose D supplementation, changes in $\mathrm{PTH}$ were significantly related to changes in directly measured free $25(\mathrm{OH}) \mathrm{D}$ but not to changes in total $25(\mathrm{OH}) \mathrm{D}$ $(128,130,131)$, suggesting that free $25(\mathrm{OH}) \mathrm{D}$ might be a better marker of the biologically available fraction at higher total $25(\mathrm{OH}) \mathrm{D}$ concentrations or when $25(\mathrm{OH}) \mathrm{D}$ is changing. Data on relationships between directly measured free $25(\mathrm{OH}) \mathrm{D}$ and bone density or markers of bone turnover are inconsistent.

\section{Other Conditions}

There are limited data on the effect of oral contraceptives or hormone replacement therapy with estrogen, but free $25(\mathrm{OH}) \mathrm{D}$ levels and relationships between total and free $25(\mathrm{OH}) \mathrm{D}$ do not appear to be significantly influenced by the use of these agents at currently prescribed dosages and routes of administration. Similarly, stable medical conditions such as hypertension, prediabetes, diabetes, osteoporosis, or mild renal disease do not appear to significantly alter relationships between free and total $25(\mathrm{OH}) \mathrm{D}$.

\section{Summary of Clinical Studies}

The impact of clinical conditions on free $25(\mathrm{OH}) \mathrm{D}$ is that the absolute level, the percent free $25(\mathrm{OH}) \mathrm{D}$ and the relationship between free and total $25(\mathrm{OH}) \mathrm{D}$ concentrations, differ in pregnant women, 336 people with cirrhosis, and elderly people with multiple morbidities compared to normals or communitydwelling outpatients. These relationships are affected to a much smaller extent by BMI in all groups. It is key that while DBP haplotype variation is associated with differences in per cent free

\section{REFERENCES}

1. Cooke NE, McLeod JF, Wang XK, Ray K. Vitamin D binding protein: genomic structure, functional domains, and mRNA expression in tissues. J Steroid Biochem Mol Biol. (1991) 40:787-93. doi: 10.1016/0960-0760(91)90304-N

2. Hagenfeldt Y, Carlstrom K, Berlin T, Stege R. Effects of orchidectomy and different modes of high dose estrogen treatment on circulating "free" and total 1,25-dihydroxyvitamin $\mathrm{D}$ in patients with prostatic cancer. $J$ Steroid Biochem Mol Biol. (1991) 39:155-9. doi: 10.1016/0960-0760(91) 90056-B
25(OH)D, the DBP haplotype effects are far smaller in magnitude than those of pregnancy, cirrhosis, or very old nursing home residents with multiple chronic conditions. Thus, total $25(\mathrm{OH}) \mathrm{D}$ measurements may be misleading in persons with altered totalto-free relationships, although for other clinical conditions the relationship between total and free $25(\mathrm{OH}) \mathrm{D}$ may be less affected.

\section{CONTRIBUTION TO THE FIELD}

$25(\mathrm{OH}) \mathrm{D}$ measurements in the blood currently provide the standard assessment of vitamin D status. Nearly all 25(OH)D circulates as the bound form, with the vitamin $\mathrm{D}$ binding protein (DBP) accounting for approximately $85 \%$ of the binding, with albumin accounting for most of the rest. However, it is the very small percentage that is not protein bound $(0.03 \%$ in normal individuals) that is able to cross the membrane of most cells. Conditions that alter levels of DBP or its binding to $25(\mathrm{OH}) \mathrm{D}$ alter the relationship between free and total levels. If the free concentration provides a more accurate assessment of vitamin $\mathrm{D}$ status, measuring only total $25(\mathrm{OH}) \mathrm{D}$ levels may be misleading in situations where the relationship between total and free $25(\mathrm{OH}) \mathrm{D}$ levels is altered as in liver disease and pregnancy or in individuals with different DBP alleles. This review examines the impact of different DBP alleles and clinical conditions that do the relationship between free and total $25(\mathrm{OH}) \mathrm{D}$ levels, concluding that in a number of clinical situations measuring the free level may provide a better index of vitamin D status than total levels in such situations.

\section{AUTHOR CONTRIBUTIONS}

All authors listed have made a substantial, direct and intellectual contribution to the work, and approved it for publication.

\section{FUNDING}

Grant support provided by: NIH AR 055924 (DB), VA I01BX003814 (DB).

\section{ACKNOWLEDGMENTS}

We appreciate the provision of data by our coauthors in our publication Schwartz et al. (40), that is included in this review.

3. Moller UK, Streym S, Heickendorff L, Mosekilde L, Rejnmark L. Effects of 25OHD concentrations on chances of pregnancy and pregnancy outcomes: a cohort study in healthy Danish women. Eur J Clin Nutr. (2012) 66:8628. doi: 10.1038/ejcn.2012.18

4. Zhang JY, Lucey AJ, Horgan R, Kenny LC, Kiely M. Impact of pregnancy on vitamin D status: a longitudinal study. Br J Nutr. (2014) 112:10817. doi: $10.1017 /$ S0007114514001883

5. Moller UK, Streym S, Jensen LT, Mosekilde L, Schoenmakers I, Nigdikar $\mathrm{S}$, et al. Increased plasma concentrations of vitamin D metabolites and vitamin $\mathrm{D}$ binding protein in women using hormonal contraceptives: a cross-sectional study. Nutrients. (2013) 5:3470-80. doi: 10.3390/nu5093470 
6. Guha C, Osawa M, Werner PA, Galbraith RM, Paddock GV. Regulation of human Gc (vitamin D-binding) protein levels: hormonal and cytokine control of gene expression in vitro. Hepatology. (1995) 21:1675-81. doi: 10.1016/0270-9139(95)90474-3

7. Dahl B, Schiodt FV, Rudolph S, Ott P, Kiaer T, Heslet L. Trauma stimulates the synthesis of Gc-globulin. Intens Care Med. (2001) 27:3949. doi: 10.1007/s001340000837

8. Schiodt FV. Gc-globulin in liver disease. Dan Med Bull. (2008) 55:131-46.

9. Wang X, Shapses SA, Al-Hraishawi H. Free and bioavailable 25Hydroxyvitamin D levels in patients with primary hyperparathyroidism. Endocr Pract. (2017) 23:66-71. doi: 10.4158/EP161434.OR

10. Bjorkhem-Bergman L, Torefalk E, Ekstrom L, Bergman P. Vitamin D binding protein is not affected by high-dose vitamin $\mathrm{D}$ supplementation: a post hoc analysis of a randomised, placebo-controlled study. BMC Res Notes. (2018) 11:619. doi: 10.1186/s13104-018-3725-7

11. Cleve H, Constans J. The mutants of the vitamin-D-binding protein: more than 120 variants of the GC/DBP system. Vox Sang. (1988) 54:21525. doi: 10.1111/j.1423-0410.1988.tb03908.x

12. Chun RF. New perspectives on the vitamin D binding protein. Cell Biochem Funct. (2012) 30:445-56. doi: 10.1002/cbf.2835

13. Malik S, Fu L, Juras DJ, Karmali M, Wong BY, Gozdzik A, et al. Common variants of the vitamin $\mathrm{D}$ binding protein gene and adverse health outcomes. Crit Rev Clin Lab Sci. (2013) 50:1-22. doi: 10.3109/10408363.2012.750262

14. Nagasawa H, Uto Y, Sasaki H, Okamura N, Murakami A, Kubo S, et al. Gc protein (vitamin D-binding protein): Gc genotyping and GcMAF precursor activity. Anticancer Res. (2005) 25:3689-95.

15. Uto Y, Yamamoto S, Mukai H, Ishiyama N, Takeuchi R, Nakagawa Y, et al. Beta-Galactosidase treatment is a common first-stage modification of the three major subtypes of Gc protein to GcMAF. Anticancer Res. (2012) 32:2359-64.

16. Calvo M, Ena JM. Relations between vitamin D and fatty acid binding properties of vitamin D-binding protein. Biochem Biophys Res Commun. (1989) 163:14-7. doi: 10.1016/0006-291X(89)92091-3

17. Bouillon R, Xiang DZ, Convents R, Van Baelen H. Polyunsaturated fatty acids decrease the apparent affinity of vitamin $\mathrm{D}$ metabolites for human vitamin D-binding protein. J Steroid Biochem Mol Biol. (1992) 42:85561. doi: 10.1016/0960-0760(92)90094-Y

18. Haddad JG, Hu YZ, Kowalski MA, Laramore C, Ray K, Robzyk P, et al. Identification of the sterol- and actin-binding domains of plasma vitamin D binding protein (Gc-globulin). Biochemistry. (1992) 31:717481. doi: 10.1021/bi00146a021

19. Head JF, Swamy N, Ray R. Crystal structure of the complex between actin and human vitamin D-binding protein at 2.5 A resolution. Biochemistry. (2002) 41:9015-20. doi: 10.1021/bi026054y

20. Zhang J, Kew RR. Identification of a region in the vitamin D-binding protein that mediates its C5a chemotactic cofactor function. J Biol Chem. (2004) 279:53282-7. doi: 10.1074/jbc.M411462200

21. Binder R, Kress A, Kan G, Herrmann K, Kirschfink M. Neutrophil priming by cytokines and vitamin D binding protein (Gc-globulin): impact on C5amediated chemotaxis, degranulation and respiratory burst. Mol Immunol. (1999) 36:885-92. doi: 10.1016/S0161-5890(99)00110-8

22. Wilson RT, Bortner JD Jr, Roff A, Das A, Battaglioli EJ, Richie JP Jr, et al. Genetic and environmental influences on plasma vitamin D binding protein concentrations. Transl Res. (2015) 165:667-76. doi: 10.1016/j.trsl.2014.08.003

23. Hirschfeld J. Immune-electrophoretic demonstration of qualitative differences in human sera and their relation to the haptoglobins. Acta Pathol Microbiol Scand. (1959) 47:160-8. doi: 10.1111/j.1699-0463.1959.tb04844.x

24. Daiger SP, Schanfield MS, Cavalli-Sforza LL. Group-specific component (Gc) proteins bind vitamin D and 25-hydroxyvitamin D. Proc Natl Acad Sci USA. (1975) 72:2076-80. doi: 10.1073/pnas.72.6.2076

25. Armas LA, Hollis BW, Heaney RP. Vitamin D2 is much less effective than vitamin D3 in humans. J Clin Endocrinol Metab. (2004) 89:538791. doi: 10.1210/jc.2004-0360

26. Bikle DD, Malmstroem S, Schwartz J. Current controversies: are free vitamin metabolite levels a more accurate assessment of vitamin D status than total levels? Endocrinol Metab Clin North Am. (2017) 46:90118. doi: $10.1016 /$ j.ecl.2017.07.013
27. Bikle DD, Gee E. Free, and not total, 1,25-dihydroxyvitamin D regulates 25-hydroxyvitamin D metabolism by keratinocytes. Endocrinology. (1989) 124:649-54. doi: 10.1210/endo-124-2-649

28. Nykjaer A, Dragun D, Walther D, Vorum H, Jacobsen C, Herz $J$, et al. An endocytic pathway essential for renal uptake and activation of the steroid 25-(OH) vitamin D3. Cell. (1999) 96:507-15. doi: 10.1016/S0092-8674(00)80655-8

29. Leheste JR, Melsen F, Wellner M, Jansen P, Schlichting U, Renner-Muller I, et al. Hypocalcemia and osteopathy in mice with kidney-specific megalin gene defect. FASEB J. (2003) 17:247-9. doi: 10.1096/fj.02-0578fje

30. Christensen EI, Birn H. Megalin and cubilin: multifunctional endocytic receptors. Nat Rev Mol Cell Biol. (2002) 3:256-66. doi: 10.1038/nrm778

31. Chun RF, Lauridsen AL, Suon L, Zella LA, Pike JW, Modlin RL, et al. Vitamin D-binding protein directs monocyte responses to 25-hydroxyand 1,25-dihydroxyvitamin D. J Clin Endocrinol Metab. (2010) 95:336876. doi: 10.1210/jc.2010-0195

32. Esteban C, Geuskens M, Ena JM, Mishal Z, Macho A, Torres JM, et al. Receptor-mediated uptake and processing of vitamin D-binding protein in human B-lymphoid cells. J Biol Chem. (1992) 267:10177-83.

33. Safadi FF, Thornton P, Magiera H, Hollis BW, Gentile M, Haddad JG, et al. Osteopathy and resistance to vitamin D toxicity in mice null for vitamin D binding protein. J Clin Invest. (1999) 103:239-51. doi: 10.1172/JCI5244

34. Zella LA, Shevde NK, Hollis BW, Cooke NE, Pike JW. Vitamin D-binding protein influences total circulating levels of 1,25-dihydroxyvitamin D3 but does not directly modulate the bioactive levels of the hormone in vivo. Endocrinology. (2008) 149:3656-67. doi: 10.1210/en.2008-0042

35. Henderson CM, Fink SL, Bassyouni H, Argiropoulos B, Brown L, Laha TJ, et al. Vitamin D-binding protein deficiency and homozygous deletion of the GC gene. N Engl J Med. (2019) 380:1150-7. doi: 10.1056/NEJMoa1807841

36. Arnaud J, Constans J. Affinity differences for vitamin D metabolites associated with the genetic isoforms of the human serum carrier protein (DBP). Hum Genet. (1993) 92:183-8. doi: 10.1007/BF00219689

37. Bouillon $\mathrm{R}$, van Baelen $\mathrm{H}$, de Moor P. Comparative study of the affinity of the serum vitamin D-binding protein. J Steroid Biochem. (1980) 13:102934. doi: 10.1016/0022-4731(80)90133-8

38. Boutin B, Galbraith RM, Arnaud P. Comparative affinity of the major genetic variants of human group-specific component (vitamin D-binding protein) for 25-(OH) vitamin D. J Steroid Biochem. (1989) 32:5963. doi: 10.1016/0022-4731(89)90014-9

39. Jones KS, Assar S, Harnpanich D, Bouillon R, Lambrechts D, Prentice A, et al. $25(\mathrm{OH}) \mathrm{D} 2$ half-life is shorter than $25(\mathrm{OH}) \mathrm{D} 3$ half-life and is influenced by DBP concentration and genotype. J Clin Endocrinol Metab. (2014) 99:337381. doi: 10.1210/jc.2014-1714

40. Schwartz JB, Gallagher JC, Jorde R, Berg V, Walsh J, Eastell R, et al. Determination of free $25(\mathrm{OH}) \mathrm{D}$ concentrations and their relationships to total 25(OH)D in multiple clinical populations. J Clin Endocrinol Metab. (2018) 103:3278-88. doi: 10.1210/jc.2018-00295

41. Lauridsen AL, Vestergaard P, Nexo E. Mean serum concentration of vitamin $\mathrm{D}$-binding protein (Gc globulin) is related to the Gc phenotype in women. Clin Chem. (2001) 47:753-6.

42. Hoofnagle AN, Eckfeldt JH, Lutsey PL. Vitamin D-binding protein concentrations quantified by mass spectrometry. N Engl J Med. (2015) 373:1480-2. doi: 10.1056/NEJMc1502602

43. Carpenter TO, Zhang JH, Parra E, Ellis BK, Simpson C, Lee WM, et al. Vitamin D binding protein is a key determinant of 25-hydroxyvitamin D levels in infants and toddlers. J Bone Mineral Res. (2013) 28:21321. doi: $10.1002 /$ jbmr.1735

44. Santos BR, Mascarenhas LP, Boguszewski MC, Spritzer PM. Variations in the vitamin D-binding protein (DBP) gene are related to lower 25hydroxyvitamin D levels in healthy girls: a cross-sectional study. Hormone Res Paediatr. (2013) 79:162-8. doi: 10.1159/000348847

45. Shao B, Jiang S, Muyiduli X, Wang S, Mo M, Li M, et al. Vitamin D pathway gene polymorphisms influenced vitamin D level among pregnant women. Clin Nutr. (2018) 37:2230-7. doi: 10.1016/j.clnu.2017.10.024

46. Fu L, Yun F, Oczak M, Wong BY, Vieth R, Cole DE. Common genetic variants of the vitamin $\mathrm{D}$ binding protein $(\mathrm{DBP})$ predict differences in response of serum 25-hydroxyvitamin D [25(OH)D] to vitamin D supplementation. Clin Biochem. (2009) 42:1174-7. doi: 10.1016/j.clinbiochem.2009.03.008 
47. Mehramiz M, Khayyatzadeh SS, Esmaily H, Ghasemi F, Sadeghi-Ardekani $\mathrm{K}$, Tayefi $\mathrm{M}$, et al. Associations of vitamin $\mathrm{D}$ binding protein variants with the vitamin D-induced increase in serum 25-hydroxyvitamin D. Clin Nutr ESPEN. (2019) 29:59-64. doi: 10.1016/j.clnesp.2018.12.005

48. Moon RJ, Harvey NC, Cooper C, D'Angelo S, Curtis EM, Crozier SR, et al. Response to antenatal cholecalciferol supplementation is associated with common vitamin D-related genetic variants. J Clin Endocrinol Metab. (2017) 102:2941-9. doi: 10.1210/jc.2017-00682

49. Wang TJ, Zhang F, Richards JB, Kestenbaum B, van Meurs JB, Berry D, et al. Common genetic determinants of vitamin D insufficiency: a genome-wide association study. Lancet. (2010) 376:180-8. doi: 10.1016/S0140-6736(10)60588-0

50. Leong A, Rehman W, Dastani Z, Greenwood C, Timpson N, Langsetmo L, et al. The causal effect of vitamin D binding protein (DBP) levels on calcemic and cardiometabolic diseases: a Mendelian randomization study. PLoS Med. (2014) 11:e1001751. doi: 10.1371/journal.pmed.1001751

51. Cheung CL, Lau KS, Sham PC, Tan KC, Kung AW. Genetic variant in vitamin $\mathrm{D}$ binding protein is associated with serum 25-hydroxyvitamin D and vitamin D insufficiency in southern Chinese. J Hum Genet. (2013) 58:749-51. doi: 10.1038/jhg.2013.84

52. Takiar R, Lutsey PL, Zhao D, Guallar E, Schneider AL, Grams ME, et al. The associations of 25-hydroxyvitamin D levels, vitamin D binding protein gene polymorphisms, and race with risk of incident fracture-related hospitalization: twenty-year follow-up in a bi-ethnic cohort (the ARIC Study). Bone. (2015) 78:94-101. doi: 10.1016/j.bone.2015.04.029

53. Speeckaert M, Huang G, Delanghe JR, Taes YE. Biological and clinical aspects of the vitamin D binding protein (Gc-globulin) and its polymorphism. Clin Chim Acta. (2006) 372:33-42. doi: 10.1016/j.cca.2006.03.011

54. Hirai M, Suzuki S, Hinokio Y, Chiba M, Kasuga S, Hirai A, et al. Group specific component protein genotype is associated with NIDDM in Japan. Diabetologia. (1998) 41:742-3. doi: 10.1007/s0012500 50980

55. Baier LJ, Dobberfuhl AM, Pratley RE, Hanson RL, Bogardus C. Variations in the vitamin D-binding protein (Gc locus) are associated with oral glucose tolerance in nondiabetic Pima Indians. J Clin Endocrinol Metab. (1998) 83:2993-6. doi: 10.1210/jcem.83.8.5043

56. Ye WZ, Dubois-Laforgue D, Bellanne-Chantelot C, Timsit J, Velho G. Variations in the vitamin D-binding protein (Gc locus) and risk of type 2 diabetes mellitus in French Caucasians. Metab Clin Exp. (2001) 50:3669. doi: 10.1053/meta.2001.20172

57. Lauridsen AL, Vestergaard P, Hermann AP, Moller HJ, Mosekilde L, Nexo E. Female premenopausal fracture risk is associated with gc phenotype. J Bone Mineral Res. (2004) 19:875-81. doi: 10.1359/JBMR.040133

58. Papiha SS, Allcroft LC, Kanan RM, Francis RM, Datta HK. Vitamin D binding protein gene in male osteoporosis: association of plasma DBP and bone mineral density with (TAAA)(n)-Alu polymorphism in DBP. Calcified Tissue Int. (1999) 65:262-6. doi: 10.1007/s002239900695

59. Ezura $Y$, Nakajima T, Kajita M, Ishida R, Inoue S, Yoshida $H$, et al. Association of molecular variants, haplotypes, and linkage disequilibrium within the human vitamin D-binding protein (DBP) gene with postmenopausal bone mineral density. J Bone Mineral Res. (2003) 18:1642-9. doi: 10.1359/jbmr.2003.18.9.1642

60. Chishimba L, Thickett DR, Stockley RA, Wood AM. The vitamin D axis in the lung: a key role for vitamin D-binding protein. Thorax. (2010) 65:456-62. doi: 10.1136/thx.2009.128793

61. Faserl K, Golderer G, Kremser L, Lindner H, Sarg B, Wildt L, et al. Polymorphism in vitamin D-binding protein as a genetic risk factor in the pathogenesis of endometriosis. J Clin Endocrinol Metab. (2011) 96:E233241. doi: 10.1210/jc.2010-1532

62. Eloranta JJ, Wenger C, Mwinyi J, Hiller C, Gubler C, Vavricka SR, et al. Association of a common vitamin D-binding protein polymorphism with inflammatory bowel disease. Pharmacogenet Genomics. (2011) 21:55964. doi: 10.1097/FPC.0b013e328348f70c

63. Abbas S, Linseisen J, Slanger T, Kropp S, Mutschelknauss EJ, Flesch-Janys $\mathrm{D}$, et al. The Gc2 allele of the vitamin D binding protein is associated with a decreased postmenopausal breast cancer risk, independent of the vitamin D status. Cancer Epidemiol Biomarkers Prev. (2008) 17:133943. doi: 10.1158/1055-9965.EPI-08-0162
64. Dimopoulos MA, Germenis A, Savides P, Karayanis A, Fertakis A, Dimopoulos C. Genetic markers in carcinoma of the prostate. Eur Urol. (1984) 10:315-6. doi: 10.1159/000463818

65. Zhou L, Zhang X, Chen X, Liu L, Lu C, Tang X, et al. GC Glu416Asp and Thr420Lys polymorphisms contribute to gastrointestinal cancer susceptibility in a Chinese population. Int J Clin Exp Med. (2012) 5:72-9.

66. Poynter JN, Jacobs ET, Figueiredo JC, Lee WH, Conti DV, Campbell $\mathrm{PT}$, et al. Genetic variation in the vitamin D receptor (VDR) and the vitamin D-binding protein (GC) and risk for colorectal cancer: results from the Colon Cancer Family Registry. Cancer Epidemiol Biomarkers Prev. (2010) 19:525-36. doi: 10.1158/1055-9965.EPI09-0662

67. McCullough ML, Stevens VL, Diver WR, Feigelson HS, Rodriguez C, Bostick $\mathrm{RM}$, et al. Vitamin D pathway gene polymorphisms, diet, and risk of postmenopausal breast cancer: a nested case-control study. Breast Cancer Res. (2007) 9:R9. doi: 10.1186/bcr1642

68. Ahn J, Albanes D, Berndt SI, Peters U, Chatterjee N, Freedman ND, et al. Vitamin D-related genes, serum vitamin D concentrations and prostate cancer risk. Carcinogenesis. (2009) 30:769-76. doi: 10.1093/carcin/bgp055

69. Martineau AR, Leandro AC, Anderson ST, Newton SM, Wilkinson KA, Nicol MP, et al. Association between Gc genotype and susceptibility to TB is dependent on vitamin D status. Eur Respir J. (2010) 35:110612. doi: 10.1183/09031936.00087009

70. Karuwanarint P, Phonrat B, Tungtrongchitr A, Suriyaprom K, Chuengsamarn S, Schweigert FJ, et al. Vitamin D-binding protein and its polymorphisms as a predictor for metabolic syndrome. Biomark Med. (2018) 12:465-73. doi: 10.2217/bmm-2018-0029

71. Xie CN, Yue M, Huang P, Tian T, Fan HZ, Wu MP, et al. Vitamin $\mathrm{D}$ binding protein polymorphisms influence susceptibility to hepatitis C virus infection in a high-risk Chinese population. Gene. (2018) 679:40511. doi: 10.1016/j.gene.2018.09.021

72. Karras SN, Koufakis T, Fakhoury H, Kotsa K. Deconvoluting the biological roles of vitamin D-binding protein during pregnancy: a both clinical and theoretical challenge. Front Endocrinol. (2018) 9:259. doi: 10.3389/fendo.2018.00259

73. Wang H, Cheng B, Chen Q, Wu S, Lv C, Xie G, et al. Time course of plasma gelsolin concentrations during severe sepsis in critically ill surgical patients. Crit Care. (2008) 12:R106. doi: 10.1186/cc6988

74. Dahl B, Schiodt FV, Ott P, Wians F, Lee WM, Balko J, et al. Plasma concentration of Gc-globulin is associated with organ dysfunction and sepsis after injury. Crit Care Med. (2003) 31:152-6. doi: 10.1097/00003246-200301000-00024

75. Kempker JA, Tangpricha V, Ziegler TR, Martin GS. Vitamin D in sepsis: from basic science to clinical impact. Crit Care. (2012) 16:316. doi: $10.1186 / \mathrm{cc} 11252$

76. Gressner OA, Gao C, Siluschek M, Kim P, Gressner AM. Inverse association between serum concentrations of actin-free vitamin D-binding protein and the histopathological extent of fibrogenic liver disease or hepatocellular carcinoma. Eur J Gastroenterol Hepatol. (2009) 21:9905. doi: 10.1097/MEG.0b013e3283293769

77. Schiodt FV, Ott P, Bondesen S, Tygstrup N. Reduced serum Gcglobulin concentrations in patients with fulminant hepatic failure: association with multiple organ failure. Crit Care Med. (1997) 25:136670. doi: 10.1097/00003246-199708000-00025

78. Lind SE, Smith DB, Janmey PA, Stossel TP. Depression of gelsolin levels and detection of gelsolin-actin complexes in plasma of patients with acute lung injury. Am Rev Respir Dis. (1988) 138:429-34. doi: 10.1164/ajrccm/138. 2.429

79. Tannetta DS, Redman CW, Sargent IL. Investigation of the actin scavenging system in pre-eclampsia. Eur J Obstetr Gynecol Reprod Biol. (2014) 172:325. doi: 10.1016/j.ejogrb.2013.10.022

80. Speeckaert MM, Wehlou C, De Somer F, Speeckaert R, Van Nooten GJ, Delanghe JR. Evolution of vitamin D binding protein concentration in sera from cardiac surgery patients is determined by triglyceridemia. Clin Chem Lab Med. (2010) 48:1345-50. doi: 10.1515/CCLM.2010.250

81. Dahl B, Schiodt FV, Gehrchen PM, Ramlau J, Kiaer T, Ott P. Gc-globulin is an acute phase reactant and an indicator of muscle injury after spinal surgery. Inflamm Res. (2001) 50:39-43. doi: 10.1007/s000110050722 
82. Koike K, Shinozawa Y, Yamazaki M, Endo T, Nomura R, Aiboshi J, et al. Recombinant human interleukin-1alpha increases serum albumin, Gcglobulin, and alphal-antitrypsin levels in burned mice. Tohoku J Exp Med. (2002) 198:23-9. doi: 10.1620/tjem.198.23

83. Meier U, Gressner O, Lammert F, Gressner AM. Gc-globulin: roles in response to injury. Clin Chem. (2006) 52:124753. doi: $10.1373 /$ clinchem.2005.065680

84. Vasconcellos CA, Lind SE. Coordinated inhibition of actin-induced platelet aggregation by plasma gelsolin and vitamin D-binding protein. Blood. (1993) 82:3648-57.

85. Mc Leod JF, Kowalski MA, Haddad JG Jr. Interactions among serum vitamin $\mathrm{D}$ binding protein, monomeric actin, profilin, and profilactin. J Biol Chem. (1989) 264:1260-7.

86. Dueland S, Nenseter MS, Drevon CA. Uptake and degradation of filamentous actin and vitamin D-binding protein in the rat. Biochem J. (1991) 274 (Pt 1):237-41. doi: 10.1042/bj2740237

87. Madden K, Feldman HA, Chun RF, Smith EM, Sullivan RM, Agan AA, et al. Critically ill children have low vitamin D-binding protein, influencing bioavailability of vitamin D. Ann Am Thorac Soc. (2015) 12:1654-61. doi: 10.1513/AnnalsATS.201503-160OC

88. Waldron JL, Ashby HL, Cornes MP, Bechervaise J, Razavi C, Thomas OL, et al. Vitamin D: a negative acute phase reactant. J Clin Pathol. (2013) 66:620-2. doi: 10.1136/jclinpath-2012-201301

89. Leaf DE, Waikar SS, Wolf M, Cremers S, Bhan I, Stern L. Dysregulated mineral metabolism in patients with acute kidney injury and risk of adverse outcomes. Clin Endocrinol. (2013) 79:491-8. doi: 10.1111/cen.12172

90. Pihl TH, Jorgensen CS, Santoni-Rugiu E, Leifsson PS, Hansen EW, Laursen I, et al. Safety pharmacology, toxicology and pharmacokinetic assessment of human Gc globulin (vitamin D binding protein). Basic Clin Pharmacol Toxicol. (2010) 107:853-60. doi: 10.1111/j.1742-7843.2010.00587.x

91. Gomme PT, Bertolini J. Therapeutic potential of vitamin D-binding protein. Trends Biotechnol. (2004) 22:340-5. doi: 10.1016/j.tibtech.2004. 05.001

92. DiMartino SJ, Trujillo G, McVoy LA, Zhang J, Kew RR. Upregulation of vitamin $\mathrm{D}$ binding protein (Gc-globulin) binding sites during neutrophil activation from a latent reservoir in azurophil granules. Mol Immunol. (2007) 44:2370-7. doi: 10.1016/j.molimm.2006.10.011

93. Trujillo G, Habiel DM, Ge L, Ramadass M, Cooke NE, Kew RR. Neutrophil recruitment to the lung in both $\mathrm{C} 5 \mathrm{a}-$ and CXCL1-induced alveolitis is impaired in vitamin D-binding protein-deficient mice. J Immunol. (2013) 191:848-56. doi: 10.4049/jimmunol.1202941

94. Shah AB, DiMartino SJ, Trujillo G, Kew RR. Selective inhibition of the C5a chemotactic cofactor function of the vitamin D binding protein by $1,25(\mathrm{OH}) 2$ vitamin D3. Mol Immunol. (2006) 43:110915. doi: 10.1016/j.molimm.2005.07.023

95. Swamy N, Ray R. Fatty acid-binding site environments of serum vitamin D-binding protein and albumin are different. Bioorg Chem. (2008) 36:1658. doi: 10.1016/j.bioorg.2008.02.002

96. Ena JM, Esteban C, Perez MD, Uriel J, Calvo M. Fatty acids bound to vitamin D-binding protein (DBP) from human and bovine sera. Biochem Int. (1989) 19:1-7

97. Yamamoto N, Homma S. Vitamin D3 binding protein (group-specific component) is a precursor for the macrophage-activating signal factor from lysophosphatidylcholine-treated lymphocytes. Proc Natl Acad Sci USA. (1991) 88:8539-43. doi: 10.1073/pnas.88.19.8539

98. Yamamoto N, Homma S, Millman I. Identification of the serum factor required for in vitro activation of macrophages. Role of vitamin D3-binding protein (group specific component, Gc) in lysophospholipid activation of mouse peritoneal macrophages. J Immunol. (1991) 147:273-80.

99. Swamy N, Ghosh S, Schneider GB, Ray R. Baculovirus-expressed vitamin D-binding protein-macrophage activating factor (DBP-maf) activates osteoclasts and binding of 25-hydroxyvitamin $\mathrm{D}(3)$ does not influence this activity. J Cell Biochem. (2001) 81:535-46. doi: 10.1002/10974644(20010601)81:3<535::aid-jcb1067>3.0.co;2-6

100. Schneider GB, Benis KA, Flay NW, Ireland RA, Popoff SN. Effects of vitamin $\mathrm{D}$ binding protein-macrophage activating factor (DBP-MAF) infusion on bone resorption in two osteopetrotic mutations. Bone. (1995) 16:65762. doi: 10.1016/8756-3282(95)00118-W
101. Korbelik M, Naraparaju VR, Yamamoto N. Macrophage-directed immunotherapy as adjuvant to photodynamic therapy of cancer. $\mathrm{Br} \mathrm{J}$ Cancer. (1997) 75:202-7. doi: 10.1038/bjc.1997.34

102. Koga Y, Naraparaju VR, Yamamoto N. Antitumor effect of vitamin D-binding protein-derived macrophage activating factor on Ehrlich ascites tumor-bearing mice. Proc Soc Exp Biol Med. (1999) 220:206. doi: 10.1046/j.1525-1373.1999.d01-3.x

103. Kisker O, Onizuka S, Becker CM, Fannon M, Flynn E, D'Amato R, et al. Vitamin D binding protein-macrophage activating factor (DBP-maf) inhibits angiogenesis and tumor growth in mice. Neoplasia. (2003) 5:3240. doi: 10.1016/S1476-5586(03)80015-5

104. Yamamoto N, Naraparaju VR, Asbell SO. Deglycosylation of serum vitamin D3-binding protein leads to immunosuppression in cancer patients. Cancer Res. (1996) 56:2827-31.

105. Yamamoto N, Naraparaju VR, Urade M. Prognostic utility of serum alpha-N-acetylgalactosaminidase and immunosuppression resulted from deglycosylation of serum Gc protein in oral cancer patients. Cancer Res. (1997) 57:295-9.

106. Recant L, Riggs DS. Thyroid function in nephrosis. J Clin Invest. (1952) 31:789-97. doi: 10.1172/JCI102664

107. Refetoff S. Thyroid hormone serum transport proteins. In: De Groot LJ, Chrousos G, Dungan K, Feingold KR, Grossman A, Hershman JM, et al., editors. Endotext, South Dartmouth, MA: MD text.com (2000).

108. Siiteri PK, Murai JT, Hammond GL, Nisker JA, Raymoure WJ, Kuhn RW. The serum transport of steroid hormones. Recent Prog Horm Res. (1982) 38:457-510. doi: 10.1016/B978-0-12-571138-8.50016-0

109. Bikle DD, Gee E, Halloran B, Haddad JG. Free 1,25-dihydroxyvitamin D levels in serum from normal subjects, pregnant subjects, and subjects with liver disease. J Clin Invest. (1984) 74:1966-71. doi: 10.1172/JCI111617

110. Bikle DD, Halloran BP, Gee E, Ryzen E, Haddad JG. Free 25hydroxyvitamin D levels are normal in subjects with liver disease and reduced total 25-hydroxyvitamin D levels. J Clin Invest. (1986) 78:74852. doi: 10.1172/JCI112636

111. Bikle D, Bouillon R, Thadhani R, Schoenmakers I. Vitamin D metabolites in captivity? Should we measure free or total $25(\mathrm{OH}) \mathrm{D}$ to assess vitamin D status? J Steroid Biochem Mol Biol. (2017) 173:105-16. doi: 10.1016/j.jsbmb.2017.01.007

112. Schwartz JB, Lai J, Lizaola B, Kane L, Weyland P, Terrault NA, et al Variability in free $25(\mathrm{OH})$ vitamin D levels in clinical populations. J Steroid Biochem Mol Biol. (2014) 144 (Pt A):156-8. doi: 10.1016/j.jsbmb.2013.11.006

113. Bikle DD, Siiteri PK, Ryzen E, Haddad JG. Serum protein binding of 1,25-dihydroxyvitamin $\mathrm{D}$ : a reevaluation by direct measurement of free metabolite levels. J Clin Endocrinol Metab. (1985) 61:96975. doi: 10.1210/jcem-61-5-969

114. Bikle DD, Gee E, Halloran B, Kowalski MA, Ryzen E, Haddad JG. Assessment of the free fraction of 25-hydroxyvitamin D in serum and its regulation by albumin and the vitamin D-binding protein. J Clin Endocrinol Metab. (1986) 63:954-9. doi: 10.1210/jcem-63-4-954

115. Schwartz JB, Lai J, Lizaola B, Kane L, Markova S, Weyland P, et al. A comparison of measured and calculated free $25(\mathrm{OH})$ vitamin D levels in clinical populations. J Clin Endocrinol Metab. (2014) 99:16317. doi: 10.1210/jc.2013-3874

116. Muller MJ, Volmer DA. Mass spectrometric profiling of vitamin D metabolites beyond 25-hydroxyvitamin D. Clin Chem. (2015) 61:103348. doi: 10.1373/clinchem.2015.241430

117. Binkley N, Carter GD. Toward clarity in clinical vitamin D status assessment: 25(OH)D assay standardization. Endocrinol Metab Clin North Am. (2017) 46:885-99. doi: 10.1016/j.ecl.2017.07.012

118. Kilpatrick LE, Phinney KW. Quantification of total vitamin-D-binding protein and the glycosylated isoforms by liquid chromatographyisotope dilution mass spectrometry. J Proteome Res. (2017) 16:4185-95. doi: 10.1021/acs.jproteome.7b00560

119. Nielson CM, Jones KS, Bouillon R, Osteoporotic Fractures in Men Research G, Chun RF, Jacobs J, et al. Role of assay type in determining free 25hydroxyvitamin D levels in diverse populations. N Engl J Med. (2016) 374:1695-6. doi: 10.1056/NEJMc1513502

120. Nielson CM, Jones KS, Chun RF, Jacobs JM, Wang Y, Hewison M, et al. Free 25-hydroxyvitamin D: impact of vitamin D binding protein assays on 
racial-genotypic associations. J Clin Endocrinol Metab. (2016) 101:222634. doi: 10.1210/jc.2016-1104

121. Lee MJ, Kearns MD, Smith EM, Hao L, Ziegler TR, Alvarez JA, et al. Free 25-hydroxyvitamin D concentrations in cystic fibrosis. Am J Med Sci. (2015) 350:374-9. doi: 10.1097/MAJ.0000000000000592

122. Sollid ST, Hutchinson MY, Berg V, Fuskevag OM, Figenschau Y, Thorsby $\mathrm{PM}$, et al. Effects of vitamin D binding protein phenotypes and vitamin D supplementation on serum total $25(\mathrm{OH}) \mathrm{D}$ and directly measured free 25(OH)D. Eur J Endocrinol. (2016) 174:445-52. doi: 10.1530/EJE-15-1089

123. Jassil NK, Sharma A, Bikle D, Wang X. Vitamin D binding protein and 25hydroxyvitamin D levels: emerging clinical applications. Endocrine Pract. (2017) 23:605-13. doi: 10.4158/EP161604.RA

124. Tsuprykov O, Buse C, Skoblo R, Haq A, Hocher B. Reference intervals for measured and calculated free 25-hydroxyvitamin $\mathrm{D}$ in normal pregnancy. $J$ Steroid Biochem Mol Biol. (2018) 181:80-7. doi: 10.1016/j.jsbmb.2018.03.005

125. van Hoof HJ, de Sevaux RG, van Baelen H, Swinkels LM, Klipping C, Ross HA, et al. Relationship between free and total 1,25-dihydroxyvitamin D in conditions of modified binding. Eur J Endocrinol. (2001) 144:3916. doi: 10.1530/eje.0.1440391

126. Walsh JS, Evans AL, Bowles S, Naylor KE, Jones KS, Schoenmakers I, et al. Free 25-hydroxyvitamin D is low in obesity, but there are no adverse associations with bone health. Am J Clin Nutr. (2016) 103:146571. doi: 10.3945/ajcn.115.120139

127. Powe CE, Evans MK, Wenger J, Zonderman AB, Berg AH, Nalls $\mathrm{M}$, et al. Vitamin D-binding protein and vitamin D status of black Americans and white Americans. N Engl J Med. (2013) 369:19912000. doi: 10.1056/NEJMoa1306357
128. Schwartz JB, Kane L, Bikle D. Response of vitamin D concentration to vitamin D3 administration in older adults without sun exposure: a randomized double-blind trial. J Am Geriatr Soc. (2016) 64:6572. doi: 10.1111 /jgs. 13774

129. Srikanth P, Chun RF, Hewison M, Adams JS, Bouillon R, Vanderschueren $\mathrm{D}$, et al. Associations of total and free 25OHD and 1,25(OH)2D with serum markers of inflammation in older men. Osteoporosis Int. (2016) 27:2291300. doi: 10.1007/s00198-016-3537-3

130. Shieh A, Chun RF, Ma C, Witzel S, Meyer B, Rafison B, et al. Effects of high-dose vitamin D2 versus D3 on total and free 25-hydroxyvitamin D and markers of calcium balance. J Clin Endocrinol Metab. (2016) 101:30708. doi: 10.1210/jc.2016-1871

131. Shieh A, Ma C, Chun RF, Wittwer-Schegg J, Swinkels L, Huijs T, et al. Associations between change in total and free 25-hydroxyvitamin D with 24,25-dihydroxyvitamin D and parathyroid hormone. J Clin Endocrinol Metab. (2018) 103:3368-75. doi: 10.1210/jc.2018-00515

Conflict of Interest Statement: The authors declare that the research was conducted in the absence of any commercial or financial relationships that could be construed as a potential conflict of interest.

Copyright (๑) 2019 Bikle and Schwartz. This is an open-access article distributed under the terms of the Creative Commons Attribution License (CC BY). The use, distribution or reproduction in other forums is permitted, provided the original author(s) and the copyright owner(s) are credited and that the original publication in this journal is cited, in accordance with accepted academic practice. No use, distribution or reproduction is permitted which does not comply with these terms. 